\title{
PARTNER READING; PUMPING UP THE STUDENTS' READING COMPREHENSION?
}

\author{
${ }^{1}$ Dedi Sumarsono, ${ }^{1}$ Ahmad Hanan, ${ }^{1}$ Abdul Kadir Bagis, ${ }^{2}$ Ayumaryani P.P. \\ ${ }^{1}$ English Language Education, Mandalika University of Education, Indonesia \\ ${ }^{2}$ English Student, Mandalika University of Education, Indonesia \\ Corresponding Author Email: dedisumarsono@ikipmataram.ac.id
}

\begin{tabular}{|c|c|}
\hline Article Info & Abstract \\
\hline $\begin{array}{l}\text { Article History } \\
\text { Received: May } 2020 \\
\text { Revised: June } 2020 \\
\text { Published: July } 2020\end{array}$ & $\begin{array}{l}\text { Partner Reading is a cooperative learning strategy in which two students work } \\
\text { together to read an assigned text. This leads the students to feel free to express } \\
\text { their prior knowledge during the discussion with their pair. This study examined } \\
\text { the effect of Partner Reading on students' reading comprehension. This research }\end{array}$ \\
\hline $\begin{array}{l}\text { Keywords } \\
\text { Partner Reading; } \\
\text { Reading Comprehension; }\end{array}$ & $\begin{array}{l}\text { was an experimental study with one group pre-test and post-test design. The } \\
\text { research was conducted at one of MTs in West Lombok. The independent } \\
\text { variable of this research was a teaching strategy that is partner reading. Students' } \\
\text { reading comprehension was considered as a dependent variable. This research } \\
\text { used all of the population as the sample. The research was analyzed through a t- } \\
\text { test with SPSS } 21 \text { software. The research reveals that teaching strategies used } \\
\text { after treatment affect significantly on the students' reading comprehension as the } \\
\text { sig- } 2 \text { tailed shows that it was less than } 0.000 \text { at the level of significance } 0.05 \text { and } \\
\mathrm{N}=24 \text {. It can be concluded that partner reading affects students' reading } \\
\text { comprehension. }\end{array}$ \\
\hline
\end{tabular}

How to cite: Sumarsono, D., Hanan, A., Bagis, A. K., \& Ayumaryani, P. P. (2020). Partner reading; Pumping up the students' reading comprehension? JOLLT Journal of Languages and Language Teaching, 8(3), 297-306, DOI: https://doi.org/10.33394/jollt.v\%vi\%i.2596

\section{INTRODUCTION}

Reading is an activity in which the reader has to obtain both explicit and implicit information from the text (Kim and Piper, 2019). Reading is the process of thinking to build meaning (Yu-hui, Li-Rong, and Yue; 2010). Reading involves the readers, the text, and the interaction between the reader and the text (Rumelhart in Aebersold and Filed, 1997: 5). Burns (1990: 151) states that the basic comprehension units in reading are words, sentences, paragraphs, and whole selection. Reading as interpreting means reacting to a written text as a piece of communication; in other words, we assume some communicative intent on the writer's part which the reader has some purpose in attempting to understand (Wallace, 1992: 4). Mitchell in Clapham (1996: 11; Harris et al., 2019) argues that reading can be defined loosely as the ability to make sense of written and printed symbols. The reader uses the symbols to guide the recovery of information from his or her memory and subsequently uses this information to construct a plausible interpretation of the writer's message.

This skill is very important for the reader in order to comprehend what is intended to deliver by the writer. Nunan in Nurkhairiyah (2017) explains that there are some reasons why it is very necessary; first, it can help the learners to enhance their knowledge because they can learn many things through reading (Jang and Ryoo, 2019). Second, reading can support the learners to master other language skills such as speaking, listening, and writing (Lee and Chen, 2019; Suadiyatno et al., 2019). In addition, reading can entertain the learners because it 
is not only done for academic purposes, but it can help the learners to refresh their minds. In other words, reading is very crucial for learners. The purpose of the reading activity is that in order the reader could learn to interact productively reading in order to determine the meaning. Reading comprehension constructs the meaning to work with a deeper understanding of concepts and information presented in a text (Rapp et al., 2007).

Besides, reading comprehension is usually a primary focus of instruction in the postprimary grades, after readers have largely mastered word recognition skills, although comprehension of text should be an integral part of reading instruction with beginning readers as well. Instruction in oral language, vocabulary, and listening comprehension should be a focus starting in preschool and continuing throughout the elementary grades (Snow.C.E, 2002: 11; Galloway and Uccelli, 2019). Furthermore, she explains that reading comprehension as the process of simultaneously extracting and constructing meaning through interaction and involvement with written language. Extracting and constructing are used to emphasize both the importance and the insufficiency of the text as a determinant of reading comprehension. Comprehension entails three elements: The reader who is doing the comprehension; The text that is to be comprehended; and The activity in which comprehension is a part. This reading comprehension process deals with the cognitive and linguistic abilities, such as vocabulary, grammar, punctuation, constructed sentences, paragraphs, and texts (Lems, Miller, \& Soro in Sumekto; 2018).

The comprehension reading also performs the activities, such as understanding the meaning of words (Lee and Chen, 2019), terms, idioms, and the expressions that used in the text, capturing the explicit meaning that contained in the text (Troyer et al., 2019), capturing the implicit meaning that contained in the text, drawing the conclusions on the content of the reading text, predicting what is going to happen after the community reads the text, and being able to evaluate the content and the language that used in the reading text (Medar \& Kenchakkanavar, 2015). A reader who can optimize his/her reading comprehension skill will be able to grab the from the text accurately as what is stated by Haerazi \& Irawan (2020) that reading needs an awareness of comprehension during reading activities. For adult readers with their comprehension skills, they can read efficiently (Yovanoff et al., in Pranowo; 2018).

In order for the students/readers are able to have good reading comprehension skills, they need to be trained with teaching methods or techniques in which they are feeling free to express their opinion about the text given without any hesitation or afraid. Cooperative Learning Strategy can be used to optimize the students' reading comprehension during the teaching and learning process. Cooperative Learning requires students to participate in various activities to do interaction, sharing, problem-solving, and open-ended outcomes. These strategies differ in the concept of traditional interaction as they focus on learning outcomes as opposed to the productive-type task (Slavin in Mubarok and Sofiana; 2017). This is in line with some principles of cooperative learning propose by Kagan and Kagan such as (1) Positive interdependence creates mutual support among students, creates peer norms favoring achievement, and increases the frequency and quality of peer tutoring; (2) Individual accountability dramatically increases student participation and motivation to achieve; (3) Equal participation; students who otherwise would not participate or who would participate very little become engaged when we equalize participation; and (4) simultaneous interaction; the amount of participation per student and our efficiency in teaching and managing the classroom increased enormously when we use simultaneous rather than sequential structures (www.KaganOnline.com).

The concept of the implementation of partner reading in the classroom is that the students are working in pairs. Stahl, Heubach, \& Crammond in Meisinger (2004) highlight that in partner reading, children are paired together for the purpose of supporting each other through the oral reading of the connected text. Partners listen, follow along, and provide 
needed words or assistance while taking turns reading, switching roles Every other page. Partner reading is used mainly as a strategy to promote the development of fluent reading by increasing the time children spend orally reading connected text. In addition, partner reading provides an opportunity for teachers to monitor children's reading progress by listening to the children read to their partners (Kuhn \& Stahl, 2000).

Like other cooperative learnings, the implementation of partner reading insists the students to work with other students who have different abilities. Besides, this strategy will lead the students to support and motivate each other during performing the activity to achieve some reading goals. In partner reading, the learning process refers to a peer-assisted intervention where students are strategically split into pairs (Kuhn \& Stahl, 2000). In pairs learning activities, higher performing students are paired with students who are having reading difficulties. The student who do not do reading activities follows along and corrects the other student whenever he or she does not understand the text provided. The reading learning activities enable students to acquire vocabulary and solve their reading difficulties (Brevik, 2019). This provides both students with additional coverage of the content material while also receiving feedback and immediate error correction (Fuchs et al., 1997).

Pertaining to the elaboration above, the empirical studies and the theoretical supports dealing with partner reading strategy and students' reading comprehension are needed to be conducted. This research is aimed at investigating to what extent partner reading strategy affects the students' reading comprehension. To support this study, the researchers start from the framework of partner reading, reading comprehension, level of reading and its principles, and macro and micro skills of reading comprehension.

\section{Partner Reading}

Partner Reading is a cooperative learning strategy in which two students work together to read an assigned text. With partner reading, it allows students to take turns reading and provide each other with feedback as a way to monitor comprehension. It provides a model of fluent reading and helps students learn decoding skills by offering positive feedback. It provides direct opportunities for a teacher to circulate in the class, observe students, and offer individual remediation (https://www.readingrockets.org/strategies/partner_reading).

Partner Reading combines elements from different approaches and puts them together for the maximum chance for the students' success. Partner reading combines repeated reading and peer-assisted learning strategies. Partner reading provides a structured reading activity that the entire class can participate in at the same time. This makes it especially helpful for teachers who do not have enough time to spend part of their day listening to students read one at a time.

In addition, classrooms are often made up of students who are a variety of different levels and because of the format of this intervention, it is helpful groups with a wide range of reading abilities (Rathvon, 2008). Partner Reading is paired students take turns reading aloud to each other. For partner reading, more fluent readers can be paired with less fluent readers. The stronger reader reads a paragraph or page first, providing a model of fluent reading. Then the less fluent reader reads the same text aloud. The stronger student gives help with word recognition and provides feedback and encouragement to the less fluent partner.

According to Meisinger, et al. (2004), partner reading extends the role of supporter and reader to both participants by including a turning taking procedure. In partner reading, children alternate the role of reader and supporter page by page through the oral reading of the text. Also, unlike paired reading, the children read the text sequentially rather than chorally. 


\section{Reading Comprehension}

Reading comprehension is the process of receiving, making sense, and interpreting information to understand language messages in written or printed form involving reader, text, and the interaction between the reader and the text. In order words, the students are not only hoped to know the words but also its meaning. Besides, reading comprehension requires a person's ability in reading, finding the information, and understanding in terms of what is already known. In this process, the reader emphasizes the information in the text. Reading comprehension itself not only deals with words but also the ability to create a new idea outside the material.

\section{Levels of Reading Comprehension}

Burns (1990: 177) divides reading comprehension into four levels. They are literal comprehension, interpretive comprehension, critical reading, and creative reading. The first level is literal comprehension. The basis of literal comprehension is recognizing stated main ideas, details, causes, and effect, and sequences. It is important because it is a prerequisite for a higher level of understanding. The second level is interpretive comprehension. Here, the skills include (1) inferring the main ideas of passage in which the main ideas are not directly stated; (2) inferring the cause and effect relationship when they are not directly stated; (3) inferring referent of pronouns; (4) inferring referent of an adverb; (4) inferring the omit words; and (6) drawing a conclusion.

The third one is critical reading. It is evaluating written material, comparing the ideas discovered with known standards and drawing conclusions about their accuracy, appropriateness, and timeliness. The critical reading must be an active reader, questioning, searching for the facts, and suspending the judgment until he or she considered all of the materials. The last level is creative reading. It involves going beyond the material presented by the authors. It requires readers to think as they read. To help the students acquire the skill of reading creatively, teachers should model the thought process involved.

Reading strategies involve ways of processing text which will vary with the nature of the text, the reader's purpose, and the context of the situation (Wallace, 1992: 57). According to Aebersold and Field (1997: 16), reading strategies are activities that the readers use in order to construct meaning from a text. These activities are sometimes called reading skills. Even though each reader has unique characteristics, successful readers also share much in common and derive more or less the same meaning from the same text as the teacher or the researcher does. Here are some strategies for reading comprehension as follows: Recognize words quickly; Use text features (subheading, transitions, etc); Use title (s) to infer what information might follow; Use word of knowledge; Analyze unfamiliar words; Identify the grammatical functions of the words; Read for meaning, concentrate on constructing meaning; Guess about the meaning of the text; Evaluate guesses and try new guesses if necessary; Monitor comprehension; Keep the purpose for reading the text in mind; Adjust strategies to the purpose for reading; Identify or infer main ideas; and Understand the relationship between the parts of the text.

\section{Micro and Macro Skills for Reading Comprehension}

Brown (2004: 187) states that reading involves two kinds of skills: micro and macro skills. The micro-skills are as follows: discriminate among the distinctive graphemes and orthographic patterns of English; retain chunks of the language of different lengths in short term memory; process writing at an efficient rate of speed to suit the purpose; recognize a core of words and interpret word order patterns and their significance; recognize the grammatical word classes (noun, verbs, etc.), systems (tense, agreement, pluralization), patterns, rules, and elliptical forms; recognize that a particular meaning may be expressed in 
different grammatical forms; recognize cohesive devices in written discourse and their role in signaling the relationship between and among the clauses.

The macro skills are as follows: recognize the rhetorical forms of written discourse and their significance for interpretation; recognize the communicative functions of written texts, according to form and purposes; infer context that is not explicit by using background knowledge; from describe events, ideas, etc., Infer links and connection between events, deduce causes and effects, and detect such relations as the main idea, supporting the idea, new information, given information, generalization, and exemplification; distinguish between literal and implied meanings; detect culturally specific references and interpret them in a context of the appropriate cultural schemata; developp and use a battery of reading strategies such as scanning and skimming, detecting discourse markers, guessing the meaning of words from the context, and activating schemata for the interpretation of the texts.

From the above theories, it can be concluded that reading comprehension is the process of receiving and interpreting information to understand language messages in written or printed form which involves reader, text, and the interaction between the reader and the text. The indicators of reading comprehension are as follows: identifying the meaning of certain words based on the context, identifying references, identifying explicit and implicit information, identifying the main idea (general idea) from the text, and identifying the communicative function of the text

\section{RESEARCH METHOD \\ Research Design}

This quantitative research is an experimental study with one group pre-test and post-test design. Ary $(2010 ; 265)$ argues that an experiment is a scientific investigation in which the researcher manipulates one or more independent variables, controls any other relevant variables, and observes the effect of the manipulations on the dependent variable(s). The onegroup pre-test-post-test design usually involves three steps: (1) administering a pretest measuring the dependent variable; (2) applying the experimental treatment $X$ to the subjects; and (3) administering a posttest, again measuring the dependent variable. Differences attributed to the application of the Experimental treatment are then evaluated by comparing the pretest and posttest scores (Ary, 2010; 304). In this research, the independent variable is the paired reading strategy and the students' reading comprehension as the dependent one. The population and the sample of this research were all of the grade VIII students of MTs NW Lingsar.

Table 1: One-Group Pretest-Posttest Design

\begin{tabular}{ccc}
\hline Pretest & Independent & Posttest \\
\hline$Y_{1}$ & $X$ & $X_{2}$ \\
\hline
\end{tabular}

\section{Instruments}

The instrument used in collecting data was reading test. The test in the form of multiple choice. The test given to the students was valid and reliable because it was designed based on the construct and the indicators of reading comprehension. In obtaining the data, the instrument was delivered to the students before and after the students were taught with partner reading

\section{Data Analysis Technique}

In analyzing the data, SPSS 21 was used to know the descriptive and inferential analysis. Descriptive analysis was used to know: Mean, Median, Mode, and Standard deviation of the reading test. Meanwhile, to test the research hypothesis, inferential analysis is 
used. It was done through t-test. The testing hypothesis is conducted in order to manage the research data which are in the form of the number so that they can produce a real conclusion. It was also used to test whether the hypothesis of the research was accepted or rejected. To know whether the treatment influence the students' reading comprehension, the mean score of pre-test and post-test were compared.

\section{RESEARCH FINDINGS AND DISCUSSION}

This research focused on the effect of paired reading strategy on students' reading comprehension. After the data were found, they were analyzed and calculated using statistical calculations as shown as follows:

Table 2. Descriptive statistics of Pre and Post test

\begin{tabular}{lllrrr}
\hline \multicolumn{7}{c}{ Paired Samples Statistics } \\
\hline \multirow{2}{*}{ Pair 1 } & Mean & N & Std. Deviation & Std. Error Mean \\
\cline { 2 - 7 } & Before_treatment & 33,8333 & 24 & 10,54871 & 2,15325 \\
\cline { 2 - 6 } & After_treatment & 71,3333 & 24 & 8,87922 & 1,81246 \\
\hline
\end{tabular}

From the examination of the mean scores in table 1, it can be concluded that there are strong differences among the groups on this measurement. As the mean score of the students after the treatment given (71.33) is higher that before the treatment (38.83). Therefore, it could be concluded that Partner Reading is more effective than the conventional strategy. It has a positive effect on the students' reading ability

Table 3. Paired Samples Test

\begin{tabular}{|c|c|c|c|c|c|c|c|c|c|}
\hline & & \multicolumn{5}{|c|}{ Paired Differences } & \multirow[t]{3}{*}{$\mathrm{t}$} & \multirow[t]{3}{*}{ df } & \multirow{3}{*}{$\begin{array}{l}\text { Sig. } \\
(2- \\
\text { tailed })\end{array}$} \\
\hline & & \multirow[t]{2}{*}{ Mean } & \multirow[t]{2}{*}{$\begin{array}{c}\text { Std. } \\
\text { Deviation }\end{array}$} & \multirow[t]{2}{*}{$\begin{array}{l}\text { Std. Error } \\
\text { Mean }\end{array}$} & \multicolumn{2}{|c|}{$\begin{array}{l}95 \% \text { Confidence } \\
\text { Interval of the } \\
\text { Difference }\end{array}$} & & & \\
\hline & & & & & Lower & Upper & & & \\
\hline \multirow[b]{2}{*}{ Pair 1} & Before_t & $-37,50000$ & 11,66563 & 2,38124 & $-42,42596$ & $-32,57404$ & $5 \overline{7}$ & 23 & ,000 \\
\hline & $\begin{array}{l}\text { After_tre } \\
\text { atment }\end{array}$ & & & & & & 48 & & \\
\hline
\end{tabular}

Table 2 summarizes that the mean difference between the two means is (37.50), the standard deviation of the difference score form all 24 students is (11.66), and the standard error the means associate with those difference score is (2.38). Confidence of the means difference shows the lower is (42.42) and the upper is (32.57), and the t value is (15.74) and the df is 23. Meanwhile, for the sig (2-tailed) 0.000 is lower than 0.005 . It indicates that there is a significant differece between the two means (students who were taught with partner reading and those who were not). On other words, it can be stated that Partner reading significantly affected and improved the students' reading comprehension.

The finding above is reasonable as partner reading is one of cooperative learning in which the students have to work in pairs. This activity made the students feel free to express their prior knowledge in reading without feeling afraid to make any mistakes. In cooperative groups, students can engage in discussions in which they construct and extend conceptual understanding of what is being learned (Johnson et al in Muliani.; 2016). This is in line with Nurhafani (2016) who found that cooperative script method towards students' interest in reading comprehension. Sumekto (2018) states that cooperative learning (the think-pair-share) approach leads a positive engagement, in which most of the group learners have a sense of 
self-awareness and confidence to solve problems and effective guidance to find the authentic learning circumstances. Mubarok and Sofiana (2017) on their finding also concluded that cooperative learning increased students' reading ability.

Teaching through the Parter reading strategy is not difficult to be implemented in the classroom as each group consisted of two students. Vaughn et al.,(2000) highlight that Partner reading is easy to implement an intervention that helps increase reading fluency especially for students who have been identified with reading disabiities or have lowachievement reading abilities. Krauss (1995) states that the use of a partner reading and writing activity is recommended to improve students' word recognition, writing, and higherlevel thought processes involved in reading. The partner reading and writing collaboration activity seemed to provide an added purpose for students' engagement in rereading and writing about their books, although rereading and writing were their least preferred classroom literacy activities (Krauss; 1995).

In the implementation of this strategy, the students have to work in pairs that lead them to play their role as they have to listen to their friends and give some response. The small groups enable students to interact, share answers, receive feedback, and practice social skills (Conderman, Bresnahan, and Hedin; 2011). During the teaching and learning process, most of the students were involved in the reading process in which it makes them ask and even answer the questions without any hesitation. It also helps the students in mastering much better. Partner reading solve the students' reading problems as more students were motivated to learn when they are in the group. It is supported by Crawford (2001: 11) stated that when a group succeeds in reaching a common goal, student members of the group experience higher selfconfidence and motivation than when students work alone.

Partner reading helps students increase reading fluency or reading comprehension (Vaughn, et al; 2000). Meisinger, et al (2004) argue that the partner reading seemed to be a successful classroom strategy in general. As evidenced by the means on the Partner Reading Rating Scale, children were generally cooperative and on-task during the sessions. This idea was in line with Alhaidari in Mubarok and Sofiana (2017) who found that the implementation of cooperative learning in reading comprehension could improve students' achievement in the cooperative partner and group activities, reach learning goals, and individual assessment. Besides, students who were taught with partner reading had more time read the passage of the text as they have taken in turn with their partner to read the text that leads the students to be more serious in reading the text. Stahl, Heubach, and Crammond (1997) state that Partner reading is used mainly as a strategy to promote the development of fluent reading by increasing the time children spend orally reading connected text. Partner reading also can serve as an enjoyable and beneficial pedagogical tool for enhancing the development of fluent reading skills (Meisinger, et al; 2004).

\section{CONCLUSION}

Partner reading strategy gave a great impact on pumping up the students' reading comprehension. It could be seen that the students enjoy the class more when they were taught with partner reading. This strategy allowed the students to express their prior knowledge freely without being afraid of making mistakes as the students feel enjoyment during the teaching and learning process. Finally, Partner reading improved the students' reading scores significantly after the treatment. 


\section{REFERENCES}

Aebersold, \& Field. 1997. From Reader to Reading Teacher. Cambridge: University Press.

Ary D. et al. (2010). Introduction to Research in Education Eighth edition. USA. Wadsworth. Belmont, CA 94002-3098

Brevik, L. M. (2019). Explicit reading strategy instruction or daily use of strategies? Studying the teaching of reading comprehension through naturalistic classroom observation in English L2. Reading and Writing, 32(9), 2281-2310. https://doi.org/10.1007/s11145019-09951-W

Brown, D. 2004. Language Assessment, Principles and Classroom Practices. New York: Pearson Education.

Burns and Roe and Ross. 1984. Teaching Reading in Today's Elementary School. NY: Houghton Mifflin Company.

Conderman, G., Bresnahan, V., \& Hedin, L. (2011).Promoting active involvement in todays classroom. Kappa Delta Pi, 47(4), 174-180.)

Crawford, L. M. (2001). Teaching contextually: Research, Rationale, and Techniques for Improving Student Motivation and Achievement

Fuchs, D., Fuchs, L., Mathes, P., \&Simmons, D. (1997) Peer assisted learning strategies: Making classroom more responsive to diversity. American Educational Research Journal, 34(1), 174-206.

Haerazi, H., \& Irawan, L. (2020). The effectiveness of ECOLA technique to improve reading comprehension in relation to motivation and self-efficacy. International Journal of Emerging Technologies in Learning (IJET), 15(01), pp. 61-76. DOI: http://dx.doi.org/10.3991/ijet.v15i01.11495

Haerazi, H., Prayati, Z., \& Vikasari, R. M. (2019). Practicing contextual teaching and learning (CTL) approach to improve students' reading comprehension in relation to motivation. English Review: Journal of English Education, 8(1), 139-146. https://doi.org/10.25134/erjee.v8i1.2011

Harris, K. R., Ray, A., Graham, S., \& Houston, J. (2019). Answering the challenge: SRSD instruction for close reading of text to write to persuade with 4th and 5th Grade students experiencing writing difficulties. Reading and Writing, 32(6), 1459-1482. https://doi.org/10.1007/s11145-018-9910-1

Jang, B. G., \& Ryoo, J. H. (2019). Multiple dimensions of adolescents' reading attitudes and their relationship with reading comprehension. Reading and Writing, 32(7), 1769-1793. https://doi.org/10.1007/s11145-018-9926-6

Johnson, D. W., Johnson, R. T., Smith, K. A. (2013). Cooperative Learning: Improving University Instruction By Basing Practice On Validated Theory. Journal on Excellence in University Teaching, 25 (3- 4), 85 - 118.

Kim, Y. S. G., \& Piper, B. (2019). Cross-language transfer of reading skills: an empirical investigation of bidirectionality and the influence of instructional environments. In Reading and Writing (Vol. 32, Issue 4). Springer Netherlands. https://doi.org/10.1007/s11145-018-9889-7

Lee, K., \& Chen, X. (2019). An emergent interaction between reading fluency and vocabulary in the prediction of reading comprehension among French immersion elementary 
students. Reading and Writing, 32(7), 1657-1679. https://doi.org/10.1007/s11145-0189920-Z

Lems, K., Miller, L. D., \& Soro, T. M. (2010). Teaching reading to English language learners: Insights fromlinguistics. New York: The Guilford Press.

Lisbeth A. Dixon-Krauss. (1995) Partner Reading and Writing: Peer Social Dialogue and The Zone of Proximal Development. Journal of Reading Behavior, 27(1).

Mubarok, H \& Sofiana, N. (2017). Cooperative Integrated Reading and Composition (CIRC) and Reading Motivation: Examining The Effect on Students' Reading Ability. Lingua Cultura, 11(2), 121-126. http://dx.doi.org/10.21512/lc.v11i2.1824

Meisinger. E.B,et al (2004). Interaction Quality during Partner Reading. J Lit Res. 2004 June 1; 36(2): 111-140. Doi: https://doi.org/10.1207/s15548430jlr3602_1

Medar, A. S., \& Kenchakkanavar, A. Y. (2015). Reading habits by the students of Karnataka Science College, Dharwad: a study. International Research: Journal of Library and Information, 5(3), 384-394.

Muliani, Maurisa S., \& Nurusshobah. (2016). Intasc Standard Cores: Raising Students' English Modality Competence. Lingua Cultura, 10(2). 111-115. http://dx.doi.org/10.21512/lc.v10i2.929

Nurhafani. (2016). The effect of cooperative script method towards students' interest in reading. Journal of Languages and Language Teaching, 4(2) 36-47.

Nurkhairiyah. (2017). Improving students' reading comprehension through Peer-Assisted Learning Strategy (PALS) at grade XI.C of MA Pondok Pesantren Daarun Nahdhah Thawalib Bangkinang (PPDN-TB) J-SHMIC, Vol 4, No 1, February 2017.

Pranowo. (2018). Developing students' reading culture for academic reading level through $\begin{array}{llll}\text { metacognitive } \quad \text { strategies. } & \text { Lingua } & \text { 67tura, } & \text { 12(1), }\end{array}$ https://doi.org/10.21512/lc.v12i1.2997

Rapp, D. N., van den Broek, P., McMaster, K. L., Kendeou, P., \& Espin, C. A. (2007). Higher-order comprehension processes in struggling readers: A perspective for research and intervention. Scientific Studies of Reading, 11(4), 289-312.

Stahl, SA.; Holubec, K.; Crammond, B.(1997) National Reading Research Center, Reading Report No. 79.University of Georgia; Athens, GA: 1997. Fluency oriented reading instruction.)

Rathvon, N. (2008) Effective School Interventions, Second Edition. New York, NY Guilford Press.

Slavin, R. E. (1995). Cooperative Learning; Theory, Research, and Practice (2nd ed.). Massachusetts: Allyn \& Bacon.

Snow.C.E. (2002 ) Reading for understanding toward a research and development program in reading comprehension. Published 2002 by RAND.1700 Main Street, P.O. Box 2138, Santa Monica, CA 90407-2138.

Suadiyatno, T., Firman, E., Hanan, A., \& Sumarsono, D. (2020). Examining the effect of contextual teaching-learning and anxiety towards students' speaking skills. JOLLT Journal of Languages and Language Teaching, 8(1), 100-107. doi: https://doi.org/10.33394/jollt.v8i1.2266 
Sumekto, D. R. (2018). Investigating the influence of think-pair-share approach toward students' reading achievement. Lingua Cultura, 12(2), 195-202.

Troyer, M., Kim, J. S., Hale, E., Wantchekon, K. A., \& Armstrong, C. (2019). Relations among intrinsic and extrinsic reading motivation, reading amount, and comprehension: a conceptual replication. Reading and Writing, 32(5), 1197-1218. https://doi.org/10.1007/s11145-018-9907-9

Urquhart. A.H and Weir C.J. 1998. Reading in a Second Language: Process, Product and Practice. NY: Addison Wesley Longman

Vaughn, S., Chard, D., Bryant, D., Coleman, M., Tyler, B., LinanThompson, S., \& Kouzekanani. (2000) Fluency and comprehension interventions or third-rade students. Remedial and Special Education 21(6), 325-335.

Wallace, C. 1996. Reading. Oxford: Oxford University Press.

Yu-hui, L., Li-rong, Z., \& Yue, N., (2010). Application of schema theory in teaching college English reading. Canadian Social Science, 6(1), 59-65.

https://www.readingrockets.org/strategies/partner_reading 